16 a 18 de autubro de 2019 - Campinas | Brasil

\title{
O UKIYO-E EM DIÁLOGO COM OS SERES FANTÁSTICOS OCIDENTAIS
}

\section{Giovana M. A. Lopes*, Luise Weiss}

\section{Resumo}

Esta pesquisa estuda as principais técnicas e processos gráficos das xilogravuras japonesas do século XIX, período conhecido como ukiyo-e, dando ênfase para os trabalhos de Hiroshige Ando e sua série chamada Uozukushi, em diálogo com o os animais imaginários listados por Jorge Luís Borges, e tendo como resultados desses estudos uma produção prática que aborda as relações citadas.

\section{Palavras-chave:}

Xilogravura, ukiyo-e, seres fantásticos, processos gráficos.

\section{Introdução}

Considerando o período do ukiyo-e, tendo como recorte as xilogravuras coloridas do século XIX, a pesquisa procura buscar as possibilidades artísticas e processos gráficos que a técnica da gravura à base d'água propicia nos campos poéticos da gravura ocidental. Entendendo a forma como ela é feita até a colocação prática em forma de produção poética autoral, tendo como especificidades a ilustração e o trabalho com criaturas imaginárias provindas das águas, retiradas e interpretadas de: BORGES, J. L. Livro dos seres imaginários (1957). No diálogo entre dois universos distintos, assim como o espaçamento temporal, serão consideradas as diferenças nos materiais, na produção, e também nos aspectos culturais presentes nos espaços trabalhados.

\section{Resultados e Discussão}

Ao longo do período da pesquisa, a partir da coleta bibliográfica, os estudos sobre as técnicas e materiais usados, assim como a contextualização histórica foram feitos em paralelo à produção autoral. Com isso, totalizando no trabalho de quatro seres imaginários, em uma média de três a cinco matrizes cada um. O primeiro teve como referencial apenas as obras de Hiroshige Ando, como uma forma de estudo da técnica, e os seguintes tiveram também o olhar sobre a literatura de Borges.

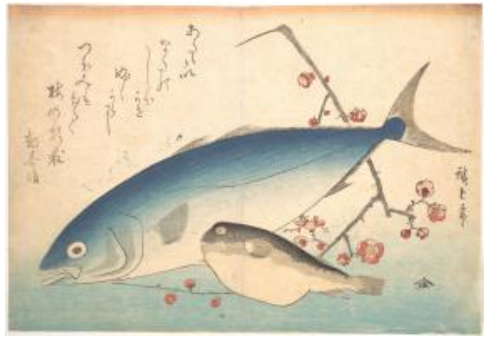

Figura 1.. HIROSHIGE ANDO. Fugu and Inaba fish. 1830s FONTE:<https://wWw.metmuseum.org/art/collection/search/55908>

Durante o processo, alguns fatores foram determinantes para os resultados gráficos, desde a temperatura influenciando na secagem das tintas, até o número de pessoas presentes na produção, enquanto as obras japonesas eram feitas em equipe, aqui, o trabalho era individual. No decorrer dos estudos, a abordagem escolhida quanto à interpretação das criaturas foi estabelecida, procurando criar um olhar poético e sensível para seres que, à princípio, não possuem tal abordagem. A última etapa do processo ocorreu na criação de um livro de artista e de um livro ilustrado, na tentativa de entender as potencialidades dessa gravura como forma de ilustração.

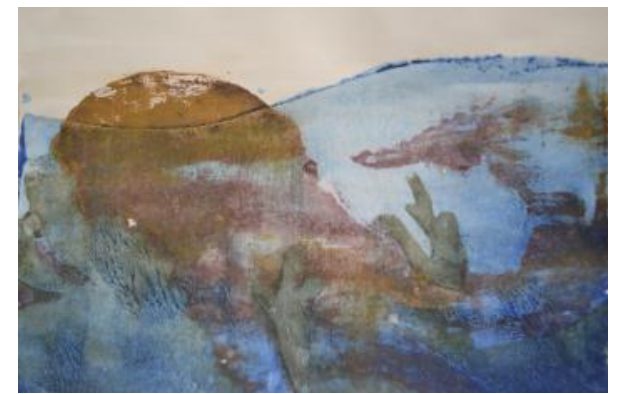

Figura 2. Kraken. Impressão de xilogravura sobre papel japonês. FONTE: Autoria própria.

\section{Conclusões}

Pôde-se notar a possibilidade desse diálogo entre a xilogravura japonesa com a temática das criaturas imaginárias, além disso, fica evidente a dificuldade em reproduzir as técnicas fielmente, sendo necessárias, por vezes, algumas adaptações, considerando também as diferenças entre os dois universos estudados. Colocado nos objetivos da pesquisa, a xilogravura à base d'água possui inúmeras formas de criação dentro das linguagens artísticas e da ilustração no Ocidente, tanto em livros ilustrados quanto livros de artista, porém trazendo uma ressignificação dos processos gráficos comumente propostos no Ocidente, sendo a produção de cópias idênticas. Enquanto a gravura base da pesquisa apresentou diferenças e características próprias em cada impressão.

\section{Agradecimentos}

Agradeço ao CNPq, juntamente à PRP e ao PIBIC Unicamp, que possibilitaram a realização e 0 financiamento desta pesquisa; à minha orientadora, Prof. $^{a}$ Dr. $^{a}$ Luise Weiss, pelas referências e pelo apoio durante todo o processo.

HASHIMOTO, Madalena. Pintura e escritura do mundo flutuante: Hishikawa Moronobu e ukiyo-e Ihara Saikaku e ukiyo-zôshi. 1.ed. São Paulo: Hedra, 2002. $448 \mathrm{p}$.

BORGES, Jorge Luis. O livro dos seres imaginários. Coautoria de Margarita Guerrero. 6. ed. São Paulo, SP: Globo, 1989. 214p

HILLIER, Jack Ronald. Japanese colour prints. 3.ed. London: Phaidon, c1991. $126 \mathrm{p}$.

UKIYO-E: pinturas do mundo flutuante. Organização de Madalena Hashimoto Cordaro. São Paulo, SP: IMS, 2008. 2v.

METROPOLITAN MUSEUM OF ART. Hiroshige: A Shoal of Fishes. 1.ed. New York, 1981. p.39. 